\title{
Influence of Western Jurisprudence over Islamic Jurisprudence: A Comparative Study
}

\author{
Syed Sarfaraj Hamid*
}

\section{Introduction}

This paper will provide the appetizer of influences of Western Jurisprudence. In modern time the science is developing, at the same time law is developing to fulfill the demand of people. In various time various people are occurring different types of crimes. Islamic Jurisprudence has played the important key role for the development and guidelines of mankind. However due to some technical changes of the society, market policy, property, cultural affairs and others Western Jurisprudence has some important contribution over Islamic Jurisprudence by which we are in a reasonable position all the way through the whole world. In this paper the attempt has been taken to focus the important field of these, by which Western Jurisprudence has played role over Islamic Jurisprudence.

\section{Western Jurisprudence: What does it Mean?}

Western Jurisprudence is basically meant common law and civil jurisprudence. Both the above two derived in western countries these two systems are still the legal system of every western countries ever some, African and Latin American countries. Western jurisprudence, concurrence (also simultaneity) is the apparent need to prove the simultaneous occurrence of both actus reus (guilty action) and mens rea (guilty mind) to constitute a crime; except in crimes of strict liability. In theory, if the actus reus does not hold concurrence in point of time with the mens rea then no crime has been committed. ${ }^{1}$ The fact that Islamic Jurisprudence originated from divine laws, almost in the sequence of social needs and changes. It has some important role for development and guidelines of mankind. In this paper, attempts will be made to be acquainted with the influence of western jurisprudence over Islamic jurisprudence.

Western Jurisprudence has basically emerged from Roman law. Hence the English term is based on the Latin word jurisprudential; Juris is the genitive form of jus meaning "law", and Prudentia means "knowledge". The word is first attested in English in 1628, at a time when the word prudence had the now obsolete meaning of "knowledge of or skill in a matter". The word may have come via the French jurisprudence, which is attested earlier. ${ }^{2}$ The most prevalent form of jurisprudence

\footnotetext{
* Associate Professor, Department of Law, Exim Bank Agricultural University Bangladesh, email: sarfaraj_shovon@yahoo.com

${ }^{1}$ Available on: http.dictionary.comlmeaninglconcurrence> accessed on 28-10-2011

${ }^{2}$ Shiner, "Philosophy of Law", Cambridge Dictionary of Philosophy
} 
seeks to analyze, explain, classify, and criticize entire bodies of law, ranging from contract to Tort to Constitutional Law. Legal encyclopedias, law reviews, and law school textbooks frequently contain this type of jurisprudential scholarship.

Western law refers to the legal traditions of Western culture. Western culture has an idea of the importance of law which has its roots in both Roman law and the Bible. As Western culture has a Greece-Roman Classical and Renaissance cultural influence, so does its legal systems. ${ }^{3}$ From the New Year, the Law English will introduce you the history of the western jurisprudence. As is known to all, jurisprudence is the basic but most crucial knowledge for all the law students. It is a basic course because we should not only make a good master of the laws, but also realize how and why the laws should be that, not be others. Moreover, this course is closely connected with many other subjects such as philosophy, sociology, ethics, political science, history, theology and even psychology. Through learning it, we can gain extensive knowledge and broaden our horizon, but also enhance our thinking ability, which will definitely benefit us in the long run. Therefore we choose this topic as the main content of our Law English in the New Year. ${ }^{4}$

Jurisprudence may be divided into three branches: analytical, sociological and theoretical. The analytical branch articulates axioms, defines terms and prescribes the methods that best enable one to view the legal order as an internally consistent, logical system. The sociological branch examines the actual effects of the law within society and the influence of social phenomena on the substantive and procedural aspects of law. The theoretical branch evaluates and citizen's law in terms of the ideals or goals postulated for it. ${ }^{5}$

\section{Characteristic of Western Jurisprudence}

The distinctive feature of common law is that it represents the law of the courts as expressed in judicial decisions. The grounds for deciding cases are found in precedents provided by past decisions, as contrasted to the civil law system, which is based on statutes and prescribed texts. Besides the system of judicial precedents, other characteristics of common law are trial by jury and the doctrine of the supremacy of the law. Originally, supremacy of the law meant that not even the king was above the law; today it means that acts of governmental agencies are subject to scrutiny in ordinary legal proceedings. ${ }^{6}$

\footnotetext{
${ }^{3}$ Available on: http://en.wikipedia.org/wiki/Western_law> accessed on 28-10-2011

${ }^{4}$ Available on: http.guofa.infolxueshulflyy\main_2_1.html> accessed on 28-10-2011

${ }^{5}$ Available on: http://www Britannica.com> accessed on 12-12011

${ }^{6}$ Available on: http://www.infoplease.com/ce6/society/A0857483.html\#ixzz1e88Pd4qU> accessed on 28-10-2011
} 
Judicial precedents derive their force from the doctrine of stare decisis [Lat. e.g.] stand by the decided matter], i.e., that the previous decisions of the highest court in the jurisdiction are binding on all other courts in the jurisdiction. Changing conditions, however, soon make most decisions inapplicable except as a basis for analogy, and a court must therefore often look to the judicial experience of the rest of the English-speaking world. This gives the system flexibility, while general acceptance of certain authoritative materials provides a degree of stability. Nevertheless, in many instances, the courts have failed to keep pace with social developments and it has become necessary to enact statutes to bring about needed changes; indeed, in recent years statutes have superseded much of common law, notably in the fields of commercial, administrative, and criminal law. Typically, however, in statutory interpretation the courts have recourse to the doctrines of common law. Thus increased legislation has limited but has not ended judicial supremacy. ${ }^{7}$

\section{Sharia Law Influenced by Western Jurisprudence}

The Islamic perspective of law's role in limiting authority stems from Islam's early days. During prophetic and Khaliph times, socially governing principles surfaced as direct interpretations from the Quran and Sunnah. With the closing of ijtihad generations later, formal opinions regarding new issues were dealt with in a fashion based on referring to earlier precedents. However, the authorities were limited in their ability to make formal opinions by the restriction on direct Quranic interpretations (on account of the end of ijtihad). The authority of a mufti, for example, would not extend beyond applying qiyas on to decisions already made. Thus the mufti existed as an implementer of existing Islamic precedents. This role is defined as such because of the limitations of Islamic jurisprudence. This trend occurred in both the Sunni and Shi'ite schools of thought. Admittedly, the concept of reason was advocated more so by the rationally driven muatazalites than their asharite counterparts who put more emphasis on the importance of tradition. Thus the limitation of authority would more likely occur amongst the mu'atazalites due to the nature of their approach to faith-based law. ${ }^{8}$ Sharia refers to the sacred law of Islam. In Western countries, where Muslim immigration is more recent, Muslim minorities have introduced Sharia family law, for use in their own disputes. Attempts to impose Sharia have been accompanied by controversy, violence, and even warfare (Second Sudanese Civil War). The recent incidents at the Arab International Festival have reinforced the poor image of Sharia inside the United States and its incompatibility with American culture and law.

Western legal philosophy recognized the limitation that codes of law created in regards to authority. Thomas Aquinas, in his explanation of natural law (the theory of

\footnotetext{
${ }^{7}$ Ibid.

${ }^{8}$ Available on: www.sodahead.com/...western...to-sharia-law> accessed on 28-03-2011
} 
what law ought to be and the principle of unchangeable frequencies among various individuals and circumstances) proposed that the coming about of natural rights limits existent authority. In other words, since natural law is concerned with things that are inherently common among all individuals and circumstances, authoritative figures are subject to the same natural rights as well and thus cannot deviate from what has naturally come to be. Therefore, policies for instance, that an authoritative figure would wish to establish would have to agree with principles already naturally in place hence there is a condition on which authority can be exerted. Another concept that both the West and Islam have embraced is the general concept of a sovereign authority one who does not obey but is obeyed. Both civilizations have recognized the existence of such individuals. John Austin introduces this figure into the realm of utilitarianism where despite the theme of observing the greater well a sovereign does not, by definition need to adhere to the will and desires of the people. ${ }^{9}$ Sharia refers to the sacred law of Islam. All Muslims believe Sharia is God's law, but they have differences between themselves as to exactly what it entails. Which will be difficult to discern what to apply when, but we'll labor along for the sake of discussion. ${ }^{10}$

\section{Western Influence on Islamic Jurisprudence}

There is no acceptable reason to accuse any non-Muslim law or economic system of lacking ethical or ideological content, because all social sciences are based on hidden value judgments which reflect the traditions, ethics and ideals of the man who formulated them. Western jurisprudence is not an exception to this rule as can be easily seen in the following words written by one of its scholars. ${ }^{11}$

There is no wonder if legal systems differ from one another because of differences in national values. And for this reason, we kept saying, for quite a long time, that we should not expect different Muslim nations to have one and the same legal or economic system even if they exert the same afford to comply with the Quran and Tradition . But, because all Muslims resort to the same legal resources, we expect their legal systems to have a great deal in common. Likewise, Western legal systems resemble one another; but differ greatly from Islamic ones, because each group has its own origin. ${ }^{12}$

All societies present an entangled mesh of values with many contradictions that never get sorted out. In America, religion is a particularly tangled strand and despite the Founding Fathers' clear intention to provide freedom of religion and separation of church and state, some Americans insist on rearguing the point continuously. In their

\footnotetext{
${ }^{9}$ Crone, Patricia, Medieval Islamic Political Thought, Edinburgh University Press, (2005), pp. 308-9

${ }^{10}$ Available on: http://the-american-catholic.com/2010/06/25/sharia-law > accessed on 28-03-2011

${ }^{11}$ Ahmed Safi El Din, Ma'alim Addastour al-Islami, Khartium, (1967), pp.12-13

${ }^{12}$ Mobdi, Muhsin, Ibn Khaldons, Philosophy of History, George Allen and unwin,London,1957, p. 214
} 
vehemence they contradict another typical value that they hold, an irrational worship of the Constitution. But that's how society is meant to be when people elect to be free.

Yet this raises the bugaboo of the Islamist factions, the religious conservatives who see the US as a sworn enemy of their faith. The west was burned by the Iranian revolution and its steady drive toward anti-Western belligerence along with its support for terrorism and the chimera of a world where every country bows to the Prophet Muhammad (SM.). A leading expert of the Arab world, Bernard Lewis, many years ago predicted that if popular uprisings succeeded in toppling the dictatorships that span from the top of Africa throughout the Middle East, the new government would be dominated by religion fundamentalism. It was a dark prophecy, and it remains the most feared prospect as viewed by the U.S. This is a long preamble to saying that Muhammad (SM.) cannot be kept out of Arab politics. The Westwardlooking elites in the Arab world are secular even sad dam was secular but they hold power by brutal means. Ironically, it was the economic rise of Egypt and Tunisia in recent years that has largely fueled the discontent in the streets, for suddenly, as in India; the poorest people see a glimmer of hope for achieving dignity and economic progress. Even so, religion will be a big part of the mix. On one side, Egypt watchers tell us that the Muslim Brotherhood won't take over the country; one is reminded of Iraq watchers who assured the neurons that invading Iraq would not lead to religious strife, given how secular that country was. ${ }^{13}$ The root that runs deepest in every Arab country is Islam, and one of the ideals of the faith is that everything in life art, politics, and law and daily habits must move around Gods.

The Islamic perspective of law's role in limiting authority stems from Islam's early days. During prophetic and caliph times, socially governing principles surfaced as direct interpretations from the Quran and Sunnah. With the closing of ijtihad generations later, formal opinions regarding new issues were dealt with in a fashion based on referring to earlier precedents. However, the authorities were limited in their ability to make formal opinions by the restriction on direct Quranic interpretation. The authority of a mufti, for example, would not extend beyond applying Qiyas on to decisions already made. Thus the mufti existed as an implementer of existing Islamic precedents. This role is defined as such because of the limitations of Islamic Jurisprudence. ${ }^{14}$ Sharia refers to the sacred law of Islam. All Muslims believe Sharia is Allah's law, but they have differences between themselves as to exactly what it entails. Which will be difficult to discern what to apply when, but we'll labor along for the sake of discussion.

\footnotetext{
${ }^{13}$ Ibid

${ }^{14}$ Available on: www. Sodaheadd. Com/....Western ...to sharia law > accessed on 28-9-2011
} 
John Austin introduces this figure into the real of utilitarianism where despite the theme of observing the greater good; a sovereign does not, by definition need to adhere to the will and desires of the people. ${ }^{15}$ In western countries, where Muslim immigration is more recent, Muslim minorities have introduced Sharia family law, for use their own disputes. Attempts to impose Sharia have been accompanied by controversy, violence, and even warfare (Second Sudanese Civil War).

As Roman law is considered to be the source of Western jurisprudence, question arises as to whether Roman law had any influence over Islamic law has been discussed by a number of scholars for a period of three centuries. It has been speculative question from the beginning and scholars were well aware of that fact. The proponents of Roman influence can be divided into two groups; direct influence and indirect influence. ${ }^{16}$ The proponents of direct influence have been advocating the view that Roman law has been directly imported and installed into main body of Islamic law. ${ }^{17}$

\subsection{Western Jurisprudence in Islamic Cultural Principles}

Islamic culture is a term primarily used in secular academia to describe the cultural practices common to historically Islamic peoples. As the religion of Islam originated in 7th century Arabia, the early forms of Muslim culture were predominantly Arab. With the rapid expansion of the Islamic empires, Muslim culture has influenced and assimilated much from the Persian, Turkic, Pakistani, Mongol, Indian, Malay, Berber, Indonesian, Greek-Roman Byzantine, Spanish, Sicilian, Balkans, Filipino and Western cultures. ${ }^{18}$

Elements of Western culture have had a very influential effect on other cultures worldwide. People of many cultures, both Western and non-Western, equate modernization (adoption of technological progress) with westernization (adoption of Western culture). Some members of the non-Western world, such as M. K. Gandhi, have suggested that the link between technological progress and certain harmful Western values provides a reason why much of "modernity" should be rejected as being incompatible with their vision and the values of their societies. These types of argument referring to imperialism and stressing the importance of freedom from it and the relativist argument that different cultural norms should be treated equally, are also present in Western philosophy. Western culture is neither homogeneous nor unchanging. As with all other cultures it has evolved and gradually changed over time. All generalities about it have their exceptions at some time and place. The organization and tactics of the Greek Hoplites differed in many ways from the

\footnotetext{
${ }^{15}$ Crone, Patricia, Medieval Islamic political thought, Edinburgh university Press, (2005) pp.308-9

${ }^{16}$ Bakhash Shaul, The reign of the Ayatollahs, Basic Books, c 1984, pp. 167-8

${ }^{17}$ Samir Amin, " The Arab Nation: some conclutions and problems", MERIP Reports, (1978) pp. 3-14

${ }^{18}$ Available on: http://en.wikipedia.org/wiki/Islamic_culture;accessed on 29-10-2011
} 
Roman legions. The polis of the Greeks is not the same as the American superpower of the $21^{\text {st }}$ century. The gladiatorial games of the Roman Empire are not identical to present-day football. The art of Pompeii is not the art of Hollywood. Nevertheless, it is possible to follow the evolution and history of the West, and appreciate its similarities and differences, its borrowings from, and contributions to, other cultures of humanity. Concepts of what is the West arose out of legacies of the Western Roman Empire and the Eastern Roman Empire. Later, ideas of the west were formed by the concepts of Christendom and the Holy Roman Empire. Western thought today is generally defined as Greco-Roman and Judeo-Christian culture, and includes the ideals of the Renaissance and the Enlightenment. ${ }^{19}$

\subsection{Western Jurisprudence in Hijab or Islamic Veil}

The hijab identifies women as followers of Islam, with it also comes tremendous responsibility. Hijab is not merely a covering dress, but more importantly, it is behavior, manners, speech and appearance in public. The headscarf is an outer manifestation of an inner commitment to worshipping. It symbolizes a commitment to piety and is a form of spiritual beauty. Self or inner morality is what gives meaning to the external scarf. The hijab is the culture of Islam worn on the bodies of Muslim women. ${ }^{20}$ The hijab is also a political symbol which calls multiculturalism into account in the West. And the respect of their cultural dress crosses the religiousgeographical divide, even in the West; people automatically have a different sphere of engagement when dealing with women in hijab. The same is true for all cultural attire; it informs behavior and in turn behavior is informed by it. The false focus on a woman head-dress is part of the Eurocentric tradition of removing the other to bring diversity into a European notion of acceptability. Thwarting the very the diversity they claim to support in their human rights. Europeans through the lens of cultural supremacy and sheer arrogance assume that the values of Europeans should be the values of the world. And unless the rest of the world is struggling to be more like them, the world is backward and oppressed. This is the continuation of the tradition in orient list thinking which misunderstood everything in African culture it saw. It is ironic that the issue of "liberation" in the West is anchored almost exclusively to sex: Freedom is an expression of excessiveness and amorality. And while they would say "choice" when it comes to Western societies, the word is "coerced, and brainwashed" for Islamic communities. However, the majority of Hollywood actresses and singers always end up half naked in FHM and they like to appease the sexualization and co modification of Western markets. Yet this is not labeled as a form of denigration and oppression. There is a serious social expectation in Western societies to sexualize women, all of them express themselves with degrees of nudity. So what is the real issue the West has with the Hijab? The Hijab is a cultural political symbol of the face of the rise of Islam. Every year more of the West sees women wearing this "alien"

\footnotetext{
${ }^{19}$ Available on: http://en.wikipedia.org/wiki/Western_culture; accessed on 29-10-2011

${ }^{20}$ Available on: http://islamandafrica.com; accessed on 29-10-2010
} 
dress on their high streets. It is a political sign of a world they have always been at odds with. But now the Muslim is again in Europe, but not with weapons of war, but weapons of culture. Now in the UK we see white skinned British girls walking down Oxford street in hijab. A serious threat to the "Europeanization" which is being diminished in the face of multiculturalism. ${ }^{21}$

\section{Western Influence over Islamic Principles in Property}

The Quran states that Allah is the sole owner of all matters in the heavens and the earth. Man, however, is Allah vice-regent on earth and holds Allah's possessions in trust (amanat). ${ }^{22}$ Islamic jurists have divided properties into three categories; Public property, State property and Private property.

\subsection{Public Property}

Public property in Islam refers to natural resources (forests, pastures, uncultivated land, water, mines, oceanic resources etc.) over which all humans have equal right. Such resources are considered the common property of the community. Such property is placed under the guardianship and control of the Islamic state, and can be utilized by any citizen, as long as it does not undermine the right of other citizens over it. $^{23}$

Some types of public property cannot be privatized under Islamic law. Muhammad (SM.) saying that "people are partners in three things: water, fire and pastures", has led some scholars to believe that the privatization of water, energy and agricultural land is not permissible. Other types of public property, such as gold mines, were allowed by Muhammad (SM.) to be privatized, in return for taxes to the Islamic state. The owner of the previously public property that was privatized has to pay zakat and, according Shiite scholars, khums as well. In general the privatization and nationalization of public property is subject to debate amongst Islamic scholars. Public property thus, eventually, becomes state or private property. ${ }^{24}$

\subsection{State Property}

State property includes certain natural resources, as well as other property that can't immediately be privatized. Islamic state property can be movable, or immovable, can be acquired through conquest, or peaceful means. Unclaimed, unoccupied and heir less properties, including uncultivated land (mawat), can be considered state property. $^{25}$

${ }^{21} \mathrm{Ibid}$

${ }^{22}$ Quran 2:107, Quran 2:255, Quran 2:284, Quran 5:120, Quran 48:14

${ }^{23}$ Nomani and Rahnema, Introduction of Islamic Law, (1994) pp. 66-70

${ }^{24}$ Ibid.

${ }^{25}$ Ibid. 
During the life of Muhammad (SM.), one fifth of military equipment captured from the enemy in the battlefield was considered state property. During his reign, Umar (on the recommendation of Ali) considered conquered land to be state property, instead of private property (as was usual practice). The reason for this was that privatizing this property would concentrate resources in the hands of a few, and prevent this property from being used for the general good of the community. The property remained under the occupation of the cultivators, but the taxes collected on it went to the state treasury. Muhammad said "Old and fallow lands are for God and His Messenger (i.e. state property), then they are for you". Jurists draw from this the conclusion that, ultimately, private ownership takes over state property. ${ }^{26}$

\subsection{Private Property}

There is consensus amongst Islamic jurists and social scientists that Islam recognizes and upholds the individual's right to private ownership. The Quran extensively discusses taxation, inheritance, prohibition against stealing, legality of ownership, recommendation to give charity and other topics related to private property. Islam also guarantees the protection of private property by imposing stringent punishments on thieves. Muhammad (SM.) said that he who dies defending his property was like a martyr. $^{27}$

Islamic economists have classified the acquisition of private property into three categories: involuntary, contractual and non-contractual. Involuntary means are inheritance, bequests, and gifts. Non-contractual is acquisition involves the collection and exploitation of natural resources that have not previously been claimed as private property. Contractual acquisition includes activities such as trading, buying, renting, hiring labor etc. ${ }^{28}$

A tradition attributed to Muhammad (SM.), with which both Sunni and Shiite jurists agree, in cases where the right to private ownership causes harm to others, then Islam is in favor of curtailing the right in those cases. Maliki and Hanbali jurists argue that if private ownership endangers public interest, then the state can limit the amount an individual is allowed to own. This view, however, is debated by others.

\section{Western Influence over Islamic Jurisprudence in Market Policing}

Islam accepts markets as the basic co-coordinating mechanism of the economic system. Islamic teaching holds that the market, through perfect competition, allows consumers to obtain desired goods, producers to sell their goods, at a mutually

\footnotetext{
${ }^{26}$ Ibid.

${ }^{27}$ Ibid, pp. $71-77$

${ }^{28}$ Ibid
} 
acceptable price. The three necessary conditions for an operational market are said to be upheld in Islamic primary sources: ${ }^{29}$

Freedom of exchange; the Quran calls on believers to engage in trade, and rejects the contention that trade is forbidden. ${ }^{30}$ Private ownership and security of contract: the Quran calls for the fulfillment and observation of contracts. The longest verse of the Quran deals with commercial contracts involving immediate and future payments. ${ }^{31}$

\section{Women's Right to Property in Arab Society and Western Civil Society}

Marriage is the union of two different names, in friendship and in love, in order to continue the posterity of the former stages, and to furnish those who shall preside at the sacrifice to heaven and earth, as those the ancestral temple, and at those at the alters to spirits of the land and grain. While it is new practice that same sex couples are being granted the same form of legal marital recognition as commonly used by mix-sex couples, recent publicity and debate over the past decade gives an impression that civil marriage for lesbian and gay couples is novel and untested. There is a long history and recorded same-sex unions around the world. ${ }^{32}$ It is believed that same sex unions were celebrated in ancient Greece and Rome, some reigns of China, such of Fujian, and at certain times in Ancient European History. ${ }^{33}$ The laws governing divorce vary substantially between sects, schools, states and cultures. A marriage can be terminated by the husband in the talaq process or by the wife seeking divorce through ' $k h u l$ '. Under faskh a marriage may be annulled or terminated by the qadi judge. Men have the right of unilateral divorce under classical Sharia. A Sunni Muslim divorce is effective when the man tells his wife that he is divorcing her, however, a Shia divorce also requires four witnesses. ${ }^{34}$ In practice, unilateral divorce is only common in a few areas of the Islamic world. If the wife asks for a divorce and the husband refuses, the wife has a right, under classical Sharia, to divorce by Khul'. Although this right is not recognized everywhere in Islam, it is becoming more common .In this scenario, the qadi judge will affect the divorce for the wife , and she may be required to return part , or all, of her dowry. ${ }^{35}$

\section{Western Influence in Land Sector (Wakf)}

The waqf in Islamic law, which developed in the medieval Islamic world from the 7th to 9th centuries, bears a notable resemblance to the English trust law. Every waqf was required to have a waqif (founder), mutawillis (trustee), qadi (judge) and

\footnotetext{
${ }^{29}$ Ibid, pp. $55-58$

${ }^{30}$ Quran 4:29, Quran 2:275 and Quran 2:279

${ }^{31}$ Quran 5:1, Quran 16:91, Quran 23:8, Quran 17:34 and Quran 70:32

${ }^{32}$ Alderson Kevin ; Lahey, Kathleen A(2004)

${ }^{33}$ Hinsch,Bret (1990)

${ }^{34}$ Omid Safi, Progressive Muslims: On Justice, One world publications, (2003).

${ }^{35}$ Omar Shahin, The Muslim Family in eastern society: A study in Islamic law (English), (2007)
} 
beneficiaries. Under both a waqf and a trust, "property is reserved, and its usufruct appropriated, for the benefit of specific individuals, or for a general charitable purpose; the corpus becomes inalienable; estates for life in favor of successive beneficiaries can be created" and "without regard to the law of inheritance or the rights of the heirs; and continuity is secured by the successive appointment of trustees or mutawillis." The only significant distinction between the Islamic waqf and English trust was "the express or implied reversion of the waqf to charitable purposes when its specific object has ceased to exist", though this difference only applied to the waqf ahli (Islamic family trust) rather than the waqf khairi (devoted to a charitable purpose from its inception). Another difference was the English vesting of "legal estate" over the trust property in the trustee, though the "trustee was still bound to administer that property for the benefit of the beneficiaries." In this sense, the "role of the English trustee therefore does not differ significantly from that of the mutawalli." ${ }^{36}$ The trust law developed in England at the time of the Crusades, during the 12th and 13th centuries, was introduced by Crusaders who may have been influenced by the waqf institutions they came across in the Middle East. ${ }^{37}$

After the Islamic waqf law and madrassah foundations were firmly established by the 10th century, the number of Bimaristan hospitals multiplied throughout Islamic lands. In the $11^{\text {th }}$ century, every Islamic city had at least several hospitals. The waqf trust institutions funded the hospitals for various expenses, including the wages of doctors, ophthalmologists, surgeons, chemists, pharmacists, domestics and all other staff, the purchase of foods and drugs; hospital equipment such as beds, mattresses, bowls and perfumes; and repairs to buildings. The waqf trusts also funded medical schools, and their revenues covered various expenses such as their maintenance and the payment of teachers and students.

The term waqf literally means detention. The legal meaning of Waqf according to Imam Abu Hanifa, is the detention of specific thing in the ownership of waqif and the devoting of its profit or products "in charity of poors or other good objects". Imam Abu Yusuf and Imam Muhammad says; Waqf signifies the extinction of the waqf's ownership in the thing dedicated and detention of all the thing in the implied ownership of God, in such a manner that its profits may revert to or be applied "for the benefit of Mankind". There is no direct injunction of the Quran regarding Waqf, but there is a hadith which says "Ibn Umar reported, Umer-Ibn-Al- Khitab got land in khyber, so he came to the prophet Muhammad (SM.) and asked him to advise him about it. The Prophet said, if you like, make the property inalienable, and give the profit from it to charity." Waqf means the permanent dedication by a Muslim of any property for any purpose recognized by the Muslim law as religious, pious or charitable. ${ }^{38}$ In effect administrator of Waqf estates results some muslim laws

\footnotetext{
${ }^{36}$ Available on: http://en.wikipedia.org/wiki/Waqf; accessed on 28-10-2011

${ }^{37}$ Ibid.

${ }^{38}$ Ibid.
} 
together with Western notions. Accordingly, the management of Wakf is undertaken by the Central Wakf Council, India, a statutory body under Government of India, which also oversees State Wakf Boards.

\section{Dual Legal System}

Many majority Muslim countries have a dual system in which the government is secular but Muslims can choose to bring familial and financial disputes to Sharia courts. The exact jurisdiction of these courts varies from country to country, but usually includes marriage, divorce, inheritance, and guardianship. Examples can be seen in Nigeria and Kenya, which have Sharia courts that rule on family law for Muslims. A variation exists in Tanzania, where civil courts apply Sharia or secular law according to the religious backgrounds of the defendants. Several countries, including Lebanon and Indonesia, have mixed jurisdiction courts based on residual colonial legal systems and supplemented with Sharia. Western countries are also exploring the idea of allowing Muslims to apply Islamic law in familial and financial disputes. Criminal law remains under the gavel of the existing legal system. "There is no reason why principles of Sharia law, or any other religious code, should not be the basis for mediation," Britain's top judge, Lord Nicholas Phillips, said in a July 2008 speech. Supporters of this initiative, such as the archbishop of Canterbury, Rowan Williams, argue that it would help maintain social cohesion (BBC) in European societies increasingly divided by religion. However, some research suggests the process to be discriminatory toward women (BBC). Other analysts suggest the system has led to grey areas." Sharia has recently become a topic of political concern in the United States. The state of Oklahoma passed a ballot measure in November 2010 to ban the use of Sharia law in court cases, which supporters are calling "a preemptive strike against Islamic law". Several opponents of new mosques being built around the United States, including one near Ground Zero, have cited fear of the spread of Sharia as a reason for opposition. And about a third of Americans in an August 2010 Newsweek poll suspect U.S. President Barack Obama sympathizes with Islamist goals to impose Sharia. ${ }^{39}$

\section{Western Jurisprudence over Islamic Jurisprudence in Judicial Sector}

The victim of a criminal act or his kinsman ("the avenger of the blood") was personally responsible for presenting a claim against the accused criminal before the court. The case then went on much like a private lawsuit. No government prosecutor participated although certain officials brought some cases to court. The classic Sharia provided for due process of law. This included notice of the claim made by the injured person, the right to remain silent, and a presumption of innocence in a fair and public trial before an impartial judge. There were no juries. Both parties in the

\footnotetext{
${ }^{39}$ Ibid.
} 
case had the right to have a lawyer present, but the individual bringing the claim and the defendant usually presented their own cases. ${ }^{40}$

At trial, the judge questioned the defendant about the claim made against him. If the defendant denied the claim, the judge then asked the accuser, who had the burden of proof, to present his evidence. Evidence almost always took the form of the direct testimony of two male witnesses of good character (four in adultery cases). Circumstantial evidence and documents were usually inadmissible. Female witnesses were not allowed except in cases where they held special knowledge, such as childbirth. In such cases, two female witnesses were needed for every male witness. After the accuser finished with his witnesses, the defendant could present his own. ${ }^{41}$ If the accuser could not produce witnesses, he could demand that the defendant take an oath before Allah that he was innocent. "Your evidence or his oath," the Prophet Muhammad taught. If the defendant swore he was innocent, the judge dismissed the case. If he refused to take the oath, the accuser won. The defendant could also confess to a crime, but this could only be done orally in open court.

In all criminal cases, the evidence had to be "conclusive" before a judge could reach a guilty verdict. An appellate system allowed persons to appeal verdicts to higher government officials and to the ruler himself. In the 19th century, many Muslim countries came under the control or influence of Western colonial powers. As a result, Western-style laws, courts, and punishments began to appear within the Sharia. Some countries like Turkey totally abandoned the Sharia and adopted new law codes based on European systems. Most Muslim countries put the government in charge of prosecuting and punishing criminal acts. In the area of family law, many countries prohibited polygamy and divorce by the husband's repudiation of his wife. ${ }^{42}$ Modern legislation along with Muslim legal scholars who are attempting to relate the will of Allah to the 20th century has reopened the door to interpreting the Sharia. This has happened even in highly traditional Saudi Arabia, where Islam began. Since 1980, some countries with fundamentalist Islamic regimes like Iran have attempted to reverse the trend of westernization and return to the classic Sharia. But most Muslim legal scholars today believe that the Sharia can be adapted to modern conditions without abandoning the spirit of Islamic law or its religious foundations. Even in countries like Iran and Saudi Arabia, the Sharia is creatively adapted to new circumstances.

\section{Western and Islamic Laws dealing with Criminal Laws}

It is believed that at the height of glory of human civilization, Satan comes to play his role. Aman becomes zalum and Jahul (Unjust and foolish) in spite of the continuous

\footnotetext{
${ }^{40}$ Available on:http:// www.crf-usa.org/ america-responds-to-terrorism/the-origins-of-islamiclaw.html>accessed on 12-11-2011

${ }^{41}$ Ibid.

${ }^{42}$ Ibid.
} 
guidance given by the creator through His Messenger and Prophet throughout ages. ${ }^{43}$ Society in the religion of Islam takes preference over an individual and it is interest of society that overrides the individual not vice- versa because any crime committed against the peace and well being of the society will be deemed as the crime against the Creator Himself. ${ }^{44}$ According to synthetic theory, no act can be called a crime if at the time the act was committed the doer was suffering from mental derangement or morbid impulse of a really irresistible type that caused the loss of the mental or emotional equilibrium." 45 According to Dr. James Seth, in virtue of his manhood and personality, "the criminal must be convinced with the righteousness of the punishment". But the question is how you are going to convince the criminal who has committed a grave criminal act like homicide, armed robbery, adultery and continuous acts of theft of the righteousness of punishment. There was the law of Allah of which he was made aware right from his childhood in a Muslim family. The Islamic Sharia has provided two kinds of punishments, one leading to learn lesson and reform and re-educate one's self not to commit a similar crime and an opportunity to rehabilitate one's self as a good and harmless member of the society. This form of light punishment is called Tazir, meaning putting to shame or disgracing the criminal for the criminal act he has committed against a member of the society or in other words against the society itself. ${ }^{46}$ The Sharia law does not sanction providing a criminal amice room instead of a cell in the prison house, good and testy foods, furniture, television and radio sets and others. ${ }^{47}$

\section{Conclusion}

This research work is completely based on a comparative study between Islamic Jurisprudence and Western Jurisprudence. In this research work it was intended to focus how Western Jurisprudence has influenced Islamic Jurisprudence, Sharia law, Islamic Cultural Principles, land sector, marketing policy and etc. Islamic Jurisprudence is the root of all. The contribution and sacrifice of Islamic Jurisprudence is up to that extent, which cannot be finished in a few lines. Besides Western Jurisprudence has followed the norms, ethics, methodologies and others of Islamic Jurisprudence by which mankind has been given a system to maintain his or her code of conduct. Thus code of conduct of human being became easy. Still we have to go ahead. So, to regulate our life and code of conduct we have to apply Islamic Jurisprudence with the touch of Sharia and influence of Western Jurisprudence.

43 Abdur Rahman, Shariah: TheIsamicLaw First published in London;(1984) p. 218

\footnotetext{
${ }^{44}$ Ibid, p. 219

${ }^{45}$ Quran, ch.6:151

${ }^{46} \mathrm{Ibid}$, p. 220

${ }^{47}$ Ibid, p. 220
} 